\title{
22: $21737223-21791778$
}

National Cancer Institute

\section{Source}

National Cancer Institute. 22:21737223-21791778. NCI Thesaurus. Code C42395.

Physical location of GNAZ_Gene 